\title{
Effect of soybean plant density on stem blight incidence
}

\author{
Monica Farias ${ }^{1} \oplus$, Ricardo Trezzi $\operatorname{Casa}^{1} \oplus$, Fernando Gava $^{2} \oplus$, Otávio Ajala Fiorentin ${ }^{1} \oplus$, \\ Mayra Juline Gonçalves ${ }^{1} \mathbb{0}$, Flávio Chupel Martins ${ }^{1} \mathbb{B}$
}

${ }^{1}$ Universidade do Estado de Santa Catarina, Av. Luiz de Camões, 2090, bairro Conta Dinheiro, Lages-SC, Brasil, CEP: 88520-000; ${ }^{2}$ BASF S.A., Sao Paulo, 04794-000 Sao Paulo, Brazil;

Endereço para correspondência: Ricardo Casa (ricardo.casa@udesc.br)

Data de chegada: 12/07/2018. Aceito para publicação em: 05/02/2019.

$10.1590 / 0100-5405 / 188813$

\section{ABSTRACT}

Farias, M.; Casa, R.T.; Gava, F.; Fiorentin, O.A.; Gonçalves, M.J.; Martins, F.C. Effect of soybean plant density on stem blight incidence. Summa Phytopathologica, v.45, n.3, p.247-251, 2019.

No-till system and high plant density are common practices in soybean crops of the Brazilian southern region, which has increased the incidence of stem and pod diseases. The objective of this study was to evaluate the effect of plant populations on stem blight incidence. The experiments were conducted in Muitos Capões Municipality, Rio Grande do Sul State, during the seasons 2006/07 and 2007/08, using cultivars BRS 255 RR and CD 213 RR. The evaluated populations had $12,18,24,30$ and 36 plants $\mathrm{m}^{-2}$, spaced $0.45 \mathrm{~m}$ between rows. The experimental plot units consisted of $5 \mathrm{~m}$ width and
$10 \mathrm{~m}$ length, arranged in randomized blocks with four replicates. Stem blight incidence was quantified at phenological stages R5.1, R5.5, R6 and R7 and the collected data underwent regression analysis. Higher soybean plant densities caused a positive and significant increase on stem blight incidence in all four phenological stages for both cultivars and seasons. There was no significant difference for soybean grain yield according to the increase in plant population. Results indicated that soybean management preventing high plant densities can contribute to reduce stem blight incidence.

Keywords: plant density, Glycine max, Phomopsis longicolla, no-till.

\section{RESUMO}

Farias, M.; Casa, R.T.; Gava, F.; Fiorentin, O.A.; Gonçalves, M.J.; Martins, F.C. Efeito da densidade de planta de soja na incidência de seca da haste. Summa Phytopathologica, v.45, n.3, p.247-251, 2019.

Plantio direto e alta população de plantas são práticas usuais em lavouras de soja na região sul do Brasil o que tem favorecido o incremento de doenças da haste e da vagem. O objetivo deste trabalho foi avaliar o efeito de populações de plantas na incidência de seca da haste. Os experimentos foram conduzidos no município de Muitos Capões, estado do Rio Grande do Sul, nas safras agrícolas de 2006/07 e 2007/08 com as cultivares BRS 255 RR e CD 213 RR. Foram avaliadas as populações de $12,18,24,30$ e 36 plantas $\mathrm{m}^{-2}$, com espaçamento entre linhas de $0,45 \mathrm{~m}$. As unidades experimentais constaram parcelas de cinco metros de largura e dez metros de comprimento, arranjadas em delineamento experimental de blocos ao acaso, com quatro repetições. A incidência da doença foi quantificada nos estádios fenológicos R5.1, R5.5, R6 e R7, sendo os dados obtidos submetidos à análise de regressão. $\mathrm{O}$ aumento na população de plantas de soja provocou incremento positivo e significativo na incidência de seca da haste nos quatro estádios fenológicos, em ambas cultivares e safras. Não foi detectada diferença significativa no rendimento de grãos de soja em função do aumento na população de plantas. Os resultados mostram que o manejo da soja evitando elevada população de plantas contribui para reduzir a incidência de seca da haste.

Palavras-chave: densidade de plantas, Glycine max, Phomopsis longicolla, plantio direto.

Brazil is the world's second largest soybean producer, only behind the United States of America. However, it is the largest exporter country and has the largest area cultivated with soybeans. The southern region is responsible for $34.7 \%$ of Brazil's total soybean area, showing 11.46 million hectares. Rio Grande do Sul State has the largest cultivated area, followed by Paraná and Santa Catarina. Together, these three States present 40.6 million tons production, corresponding to $35.6 \%$ of the total Brazilian soybean production (5).

The adoption of no-till system in the southern Brazilian fields brought several benefits such as substantial reduction in soil erosion, increase in nutrient conservation, increase in soil biodiversity, decrease in water losses and reduction in soil temperature fluctuations (7). However, monoculture in no-till system associated with high plant density has increased plant diseases, such as stem blight, caused by the fungus Phomopsis longicolla (T.W Hobbs) [sin. Phomopsis sojae (Lehman)]. This fungus survives as pycnidia and perithecia in soybean straw that remains in the no-till system and as mycelium in infected seeds. Raindrops promote inoculum dispersion from the pycnidia to the stems and pods, where it starts the infection process. The causal agent requires a long humidity period on the infection sites to infect rods and pods $(12,13)$.

The use of resistant cultivars is one of the most efficient measures to control diseases; however, genetic resistance aiming at stem blight control has not been successfully obtained by breeding programs. In addition, chemical control has not been satisfactory for this disease since fungicide application using traditional methods cannot efficiently reach the stems and pods which are located in the lower layers of the plant (14). Using healthy or treated seeds with specific fungicides 
associated with crop rotation is a commonly used strategy to control soybean diseases. Practices such as choosing species to integrate a crop succession system, balanced nutrition, water management and plant density have been less explored and studied for plant disease integrated management $(10,13)$

A high number of plants per area results in an environment with lower luminosity and more humidity since leaf overlapping promotes a longer wetness duration on the infection sites, reflecting in lower aeration and solar incidence; therefore, the water remains longer time on the aerial part of the plants (6). Lower plant densities favor the plant development since there is an improvement in the use of photosynthetically active radiation and greater aeration in the plant canopy due to their mobility between leaves and branches $(1,16)$.

The sowing density indicated by research and technical assistance is approximately 24 to $30 \mathrm{~m}^{-2}$ seeds. However, due to variations in seed germination rates, the number of seeds used by soybean producers has been greater. The objective of this study was to evaluate the effect of plant density on stem blight incidence in soybeans cultivated under no-till system.

\section{MATERIAL AND METHODS}

The experiments were conducted in the 2006/07 and 2007/08 crop seasons at NBN Sementes Farm, located in Muitos Capões Municipality,

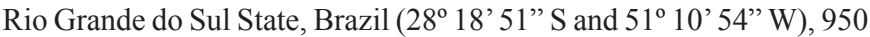
$\mathrm{m}$ above sea level. The soil is classified as Dystrophic Red Latosol, showing organic matter content around 6\%, pH 5.6, phosphorus levels between 8 and $12 \mathrm{ppm}$ and potassium above $200 \mathrm{ppm}$.

Soybean was sown on December 8 and 12, 2006 and 2007, respectively. The experiment was established in a no-till system area, in crop rotation with corn and in succession with wheat. Cultivars BRS $255 \mathrm{RR}$ and CD $213 \mathrm{RR}$ were used in both years. The cultivar BRS $255 \mathrm{RR}$ belongs to the early maturation group of determined growth, total cycle of approximately 136 days (in regions above $800 \mathrm{~m}$ altitude) and recommendation of 22 to 27 plants $\mathrm{m}^{-2}$, while the cultivar CD 213 RR has earlier development, showing determined growth, cycle of approximately 123 days and density of 18 to $29 \mathrm{~m}^{-2}$ plants in regions of altitude higher than $500 \mathrm{~m}$.

Sowing was performed at a high plant density. In the V1 stage (fully developed leaves of the cotyledon node according to the phenological scale of Fehr et al.) (9), a roughing process was done to obtain the desired plant densities of $12,18,24,30$ and 36 plants $\mathrm{m}^{-2}$, spaced $0.45 \mathrm{~m}$ between lines. Soil fertilization consisted of phosphorus application in the sowing line ( $200 \mathrm{~kg} \mathrm{ha}^{-1} 00-42-00$ formula) and potassium chloride on the soil surface (100 $\mathrm{kg} \mathrm{ha}^{-1} 00-00-60$ formula), both available for wheat.

Experimental units consisted of $5 \mathrm{~m}$-wide and $10 \mathrm{~m}$-long plots arranged in a randomized block design with four replicates.

Stem blight incidence was randomly evaluated in 20 plants per plot by identifying and counting the plants with disease symptoms (stem necrosis and pycnidia linearly distributed in infected tissues). In both cultivars and seasons, the disease assessments were done in the phenological stages in which there was 10\% grain filling (R5.1), most of the pods were between $75 \%$ and $100 \%$ grain filling (R5.5), $100 \%$ grain filling and green leaves (R6) and beginning of leaf yellowing (R7) (9).

To evaluate soybean yield, the plants in five linear meters of four rows from the center of the plot were collected and manually harvested. The plants were treashed on a stationary electric powered combine.
The grains were cleaned and subsequently weighed. Grain yield was calculated as $\mathrm{kg} \mathrm{ha}^{-1}$ at $13 \%$ humidity.

Stem blight incidence data were transformed by using the Poison Coefficient (square root $[x+1]$ ) and, together with grain yield data, were subjected to analysis of variance. The degrees of freedom in the interaction of the results were used by means of simple effect. The results of the relationship between plant population and disease incidence in different phenological stages were subjected to regression analysis. Grain yield averages were compared according to $F$ test (1\%). The analyses were conducted by using PROC GLM in the SAS system, version 9.2 (17).

\section{RESULTS AND DISCUSSION}

For both 2006/2007 and 2007/2008 crop seasons, in the period from soybean emergence (December - second week) to defoliation (end of April), environmental conditions were favorable for occurrence of stem blight in cultivars CD 213 RR and BRS 255 RR (Figure 1), and the disease incidences were higher than $40 \%$ in the first reproductive stages (Figure 2). For the 2007 season, the highest disease incidence was observed in all phenological stages, especially due to the $900 \mathrm{~mm}$ precipitation during the productive cycle. In the 2008 season, precipitation was $531 \mathrm{~mm}$ (Figure 1).

There was a significant difference according to $F$ test at $1 \%$ significance level for year, phenological stage and plant density. However, it did not occur for both soybean cultivars, which indicates that they had the same behavior in relation to disease incidence considering the tested plant density and the two harvest periods. There was a significant interaction between the analyzed variables, except for quadruple interaction of crop season $\mathrm{x}$ cultivars $x$ phenological stage $x$ plant density and triple interaction of cultivars x phenological stage x plant density.

Regression analysis was performed between stem blight incidence and plant density for each phenological stage and year separately (Figure 2A, B). Seven positive linear regression equations were generated, except for the phenological stage R5.1 in the 2008 harvest (Figure 1B). Thus, for the tested plant density range, as the population increased, the incidence of soybean stem blight increased in the four phenological stages, except for R5.1 stage in 2008 (Figure 2A, B). In both crop seasons, the disease incidence was lowest for 12 plants $\mathrm{m}^{-2}$ and highest for 36 plants $\mathrm{m}^{-2}$ in all stages (Figure 1A, B). These results show that a linear increase in the soybean density leads to a gradual increase in the disease incidence.

The recommended plant density usually varies with the cultivar and the rainfall in the region (volume and distribution) during the stand establishment period and the vegetative stage, as well as the interaction between these factors. However, most studies and soybean seed companies have recommended densities between 24 and 33 plants $\mathrm{m}^{-2}$, usually ignoring the technological level used by the farmer. A higher incidence of diseases can be explained by populations that interfere with the soybean growth, reflecting on the humidity and aeration of the canopy and resulting in a longer wetness period at the infection sites (16). In addition to the increased wetness period that is required by the pathogen, high plant populations may cause nutritional imbalance, thinner stems and greater vulnerability to water stress, which may predispose the crop to infection. The higher the plant density, the wider the final height and 


\section{Crop Season 2006/2007}

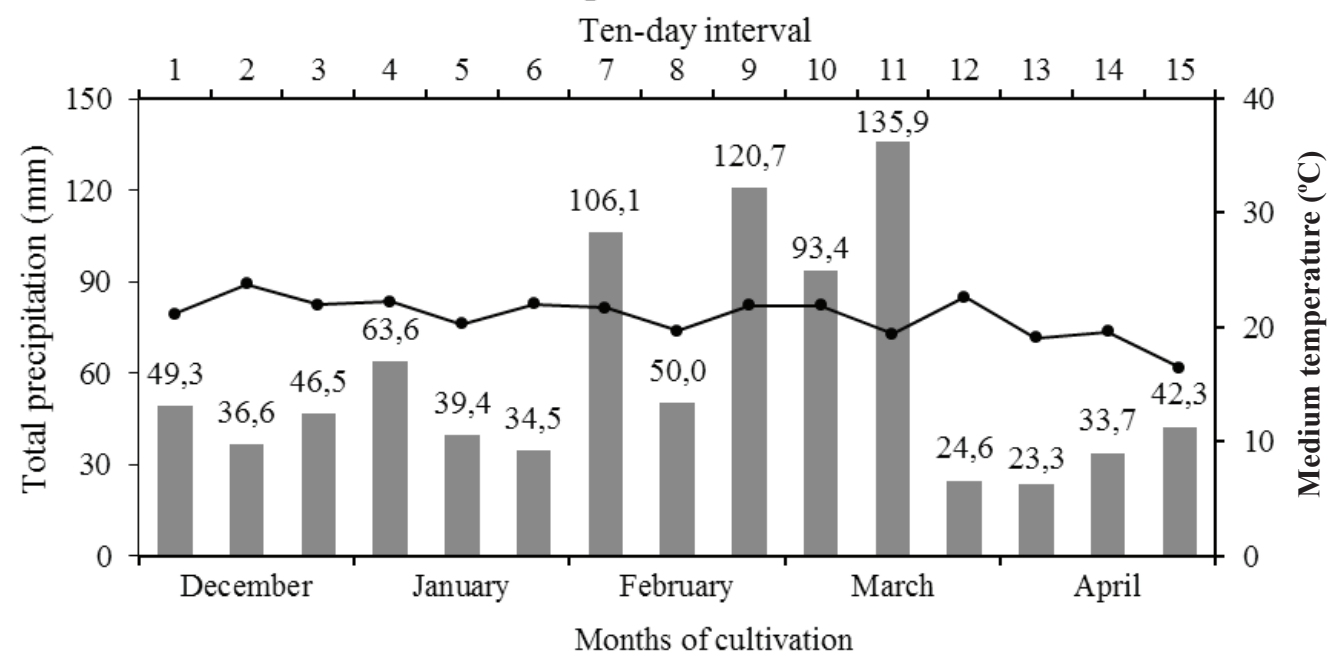

Total precipitation $(\mathrm{mm}) \rightarrow$ Medium temperature

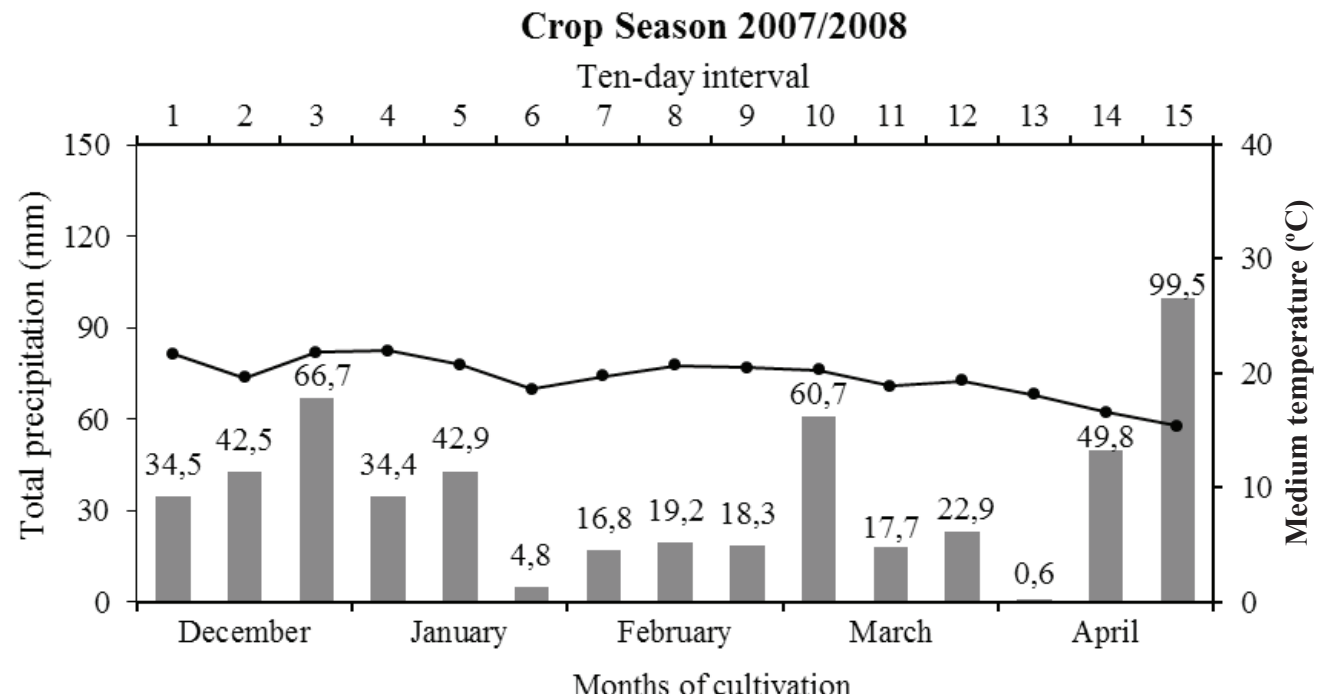

Total precipitation $(\mathrm{mm}) \rightarrow$ Medium temperature

Figure 1. Total precipitation $(\mathrm{mm})$ and medium temperature $\left({ }^{\circ} \mathrm{C}\right)$ recorded in the $2006 / 07$ and $2007 / 08$ crop seasons, corresponding to the period from emergency to defoliation of soybean plants in Muitos Capões Municipally, Rio Grande do Sul State.

the smaller the stem diameter; these factors may favor the incidence of stem diseases $(10,15)$. Higher plant densities also result in weeding and lodging, contributing to reduced yield and making the plants more vulnerable to stem diseases (18).

In this study, no significant difference in soybean yield was detected for cultivars CD 213 RR and BRS 255 RR as a function of the increased plant density (Figure 3 ). The low population did not affect the yield probably because the soil fertility was adequate and the soybean crop plasticity was high, which is characteristic of this plant species (3). According to Balbinot Junior et al. (2), at lower plant densities, the number of pods per plant, grains per plant and a thousand grain mass were higher due to adaptive characteristics that confer the soybean crop the same production capacity in different spatial arrangements. Although there was a higher incidence of stem blight in higher populations, there was no significant reduction in grain yield, which can be attributed to the compensation provided by the change in several components of the production and by the insufficient stem damage severity and filling grains. Similar results were obtained by Fawcett et al. (8). According to Garcia et al. (11), the non-increase in soybean yield with the increase in plant density may be due to the higher intraspecific competition that results in decreased branching per plant and consequently reduced productivity. Similar results were found by Carpenter \& Board (4), who even worked with extreme populations, ranging from 7 to 63 plants $\mathrm{m}^{-2}$, and did not observe significant variations in soybean yield.

There was a significant difference in yield between cultivars, between years and for the cultivar x year interaction. In the 2007 harvest, there was no significant difference in yield comparing the cultivars; however, there were differences in the yield of cultivars 

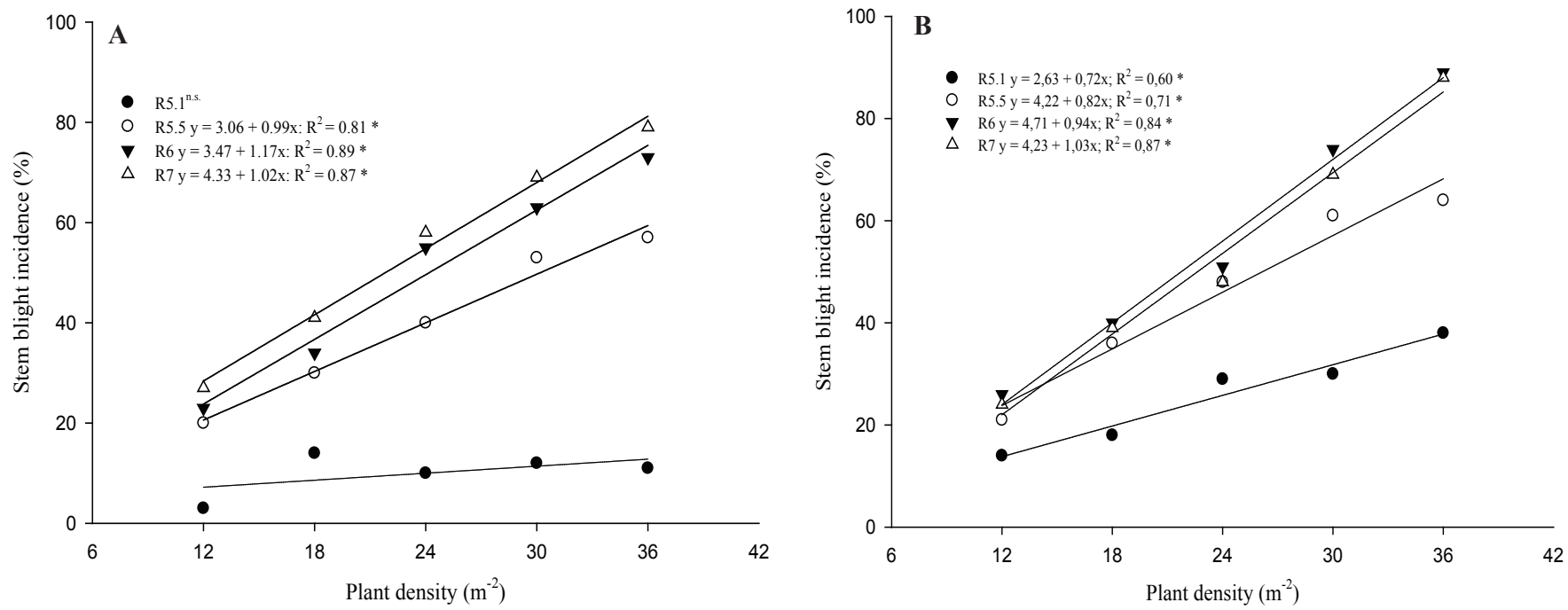

Figure 2. Regression analysis between stem blight incidence (\%) and the five plant populations tested ( $\mathrm{m}^{-2}$ ) at the phenological stages R5.1 (10\% granulation), R5.5 (most of the pods between $75 \%$ and $100 \%$ granulation), R6 (100\% granulation and green leaves), R7 (beginning of leaf yellowing), in 2007 (A) and 2008 (B) crop seasons. *significant at 1\% significance level according to F; n.s. = not significant.
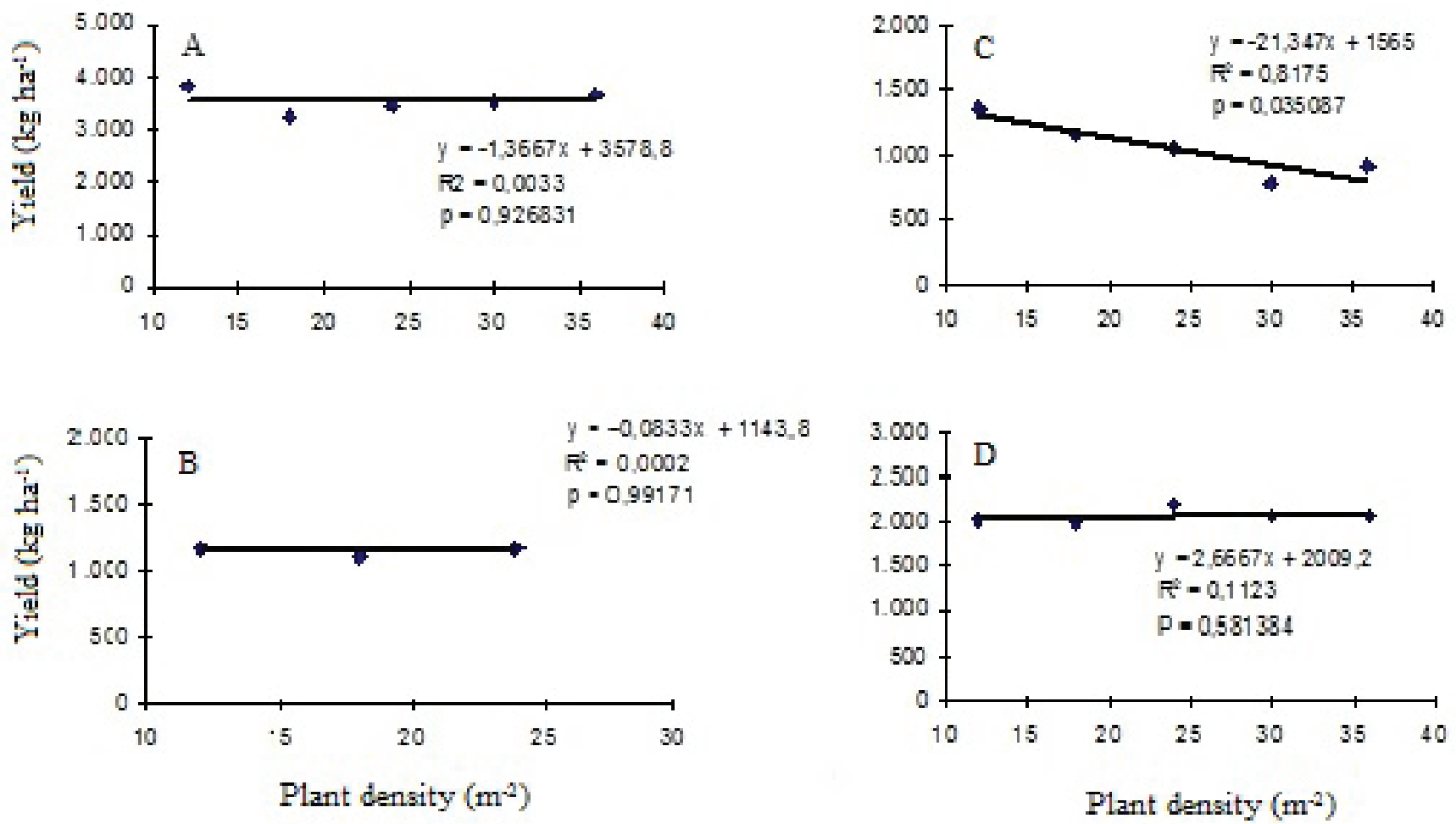

Figure 3. Regression analysis between yield and plant density of soybean plant cultivars CD 213 RR (A and B) and BRS 255 RR (C and D) during the 2006/07 (A and C) and 2007/08 (B and D) crop seasons at Muitos Capões Municipally, Rio Grande do Sul State.

Table 1. Yield of soybean cultivars CD $213 \mathrm{RR}$ and BRS $255 \mathrm{RR}$ in the 2007 and 2008 crop seasons, compared according to $F$ test.

\begin{tabular}{lcc}
\hline \multirow{2}{*}{ Soybean Cultivar } & \multicolumn{2}{c}{ Yield $\left(\mathbf{k g ~ h}^{-1}\right)$} \\
\cline { 2 - 3 } & $\mathbf{2 0 0 7}$ & $\mathbf{2 0 0 8}$ \\
\hline CD 213 RR & $3,516 \mathrm{aA}$ & $1.148 \mathrm{aB}$ \\
BRS 255 RR & $3,185 \mathrm{aA}$ & $2.088 \mathrm{bB}$
\end{tabular}

Averages followed by the same lowercase letter in the columns and uppercase letter on the lines do not differ significantly according to $F$ test (1\%). considering the different crop seasons (Table 1). This fact can be explained by the lower water availability in the 2007/08 crop, which culminated in the lower yield of both cultivars when compared to the 2006/07 production cycle (Figure 1A, B). The cultivar BRS 255 RR showed higher yield in the 2008 crop (Table 1).

This study led to the conclusion that the chosen plant density interferes in the integrated management of soybean stem blight, since higher plant densities result in higher disease incidence and does not result in yield increases. 


\section{REFERENCES}

1. Ballaré, C.L.; Scopel, A.L.; Sánchez, R.A. Plant photomorphogenesis in canopies, crop growth, and yield. Hort Science, St. Joseph, v.30, n.6, p.1172-1181, 1995

2. Balbinot Junior, A.A.; Procópio, S.O.; Debiasi, H.; Franchini, J.C.; Panison, F. Semeadura cruzada em cultivares de soja com tipo de crescimento determinado. Semina: Ciências Agrárias, Londrina, v.36, n.3, p.1215-1226, 2015. Available at: $<$ http://www.uel.br/revistas/uel/index.php/semagrarias/ article/view/14900>. Accessed on: 22 ago. 2017.

3. Büchling, C.; Oliveira Neto, A.M.; Guerra, N.; Bottega, E.L. Uso da plasticidade morfológica como estratégia para a redução da população de plantas em cultivares de soja. Agrarian, Dourados, v.10, n.35, p.22-30, 2017. Available at: <http://ojs.ufgd.edu.br/index.php/agrarian/article/view/3931>. Accessed on: 10 out. 2017.

4. Carpenter, A.C.; Board, J.E. Branch yield components controlling soybean yield stability across plant populations. Crop Science, Madison, v.37, p.885-891, 1997.

5. Companhia Nacional de Abastecimento - CONAB. Acompanhamento da Safra Brasileira - Grãos - $\mathbf{1 2}^{\circ}$ Levantamento. 2017. Available at: $<$ http:// www.conab.gov.br/OlalaCMS/uploads/arquivos/16 $0909 \quad 09 \quad 15 \quad 18 \quad 32$ boletim_12_setembro.pdf $>$. Accessed on: 10 set. $201 \overline{7}$.

6. CONAB. Acompanhamento de safra brasileira: grãos, décimo segundo levantamento. Companhia Nacional de Abastecimento, Brasília, 2017, v.4. <http://www.conab.gov.br/OlalaCMS/uploads/arquivos/16_09_09_15_18_32_boletim_12_setembro.pdf $>$. Accessed on: 10 set. 2017.

7. Dalmago, G.A.; Cunha, G.R.; Pires, J.L.F; Santi, A.; Fochesatto, E. Potencial de aplicação da Agrometeorologia em Agricultura de Precisão para produção de grãos. In: Bernardi, A.C.C.; Naime, J.M.; Resende, A.V.; Inamasu, R.Y.; Bassoi, L.H. (Ed.). Agricultura de precisão: resultados de um novo olhar. Brasília, DF: Embrapa, 2014. cap.31, p.331-337.

8. Debiasi, H.; Franchini, J.C.; Conte, O.; Balbinot Junior, A.A.; Torres, E.; Saraiva, O.F.; Oliveira, M.C.N. Sistemas de preparo do solo: trinta anos de pesquisas na Embrapa Soja. Londrina: Embrapa, 2013. 76p.
9. Fawcett, J.; Sievers, J.; Dejong, J.; Rossiter, L. On-Farm Corn and Soybean Planter Trials: Farm Progress Reports. Farm Progress Reports, Iowa, v.1, n.112,p.45-49,2017. Available at: $<$ http://lib.dr.iastate.edu/farmprogressreports/vol2016/iss1/112/?utm_source=lib.dr.iastate.edu/farmprogressreports/ vol2016/iss1/112\&utm medium=PDF\&utm campaign=PDFCoverPages $>$ Accessed on: 30 set. 2017.

10. Fehr, W.R.; Caviness, C.E.; Burmood, D.T.; Pennington, J.S. Stage of development descriptions for soybeans, Glycine max (L.) Merrill. Crop Science, Madison, v.11, p.929-931, 1971.

11. Freitas, M.A.; Café Filho, C.A.; Nasser, L.C.B. Cultural practices and genetic resistance as factors affecting soybean stem canker and plant yield in the Cerrado. Fitopatologia Brasileira, Brasília, DF, v.27, p.290, 2002

12. Garcia, R.A.; Richetti, A.; Sutier, G.A.S. Arranjos Alternativos de Plantas de Soja: Viabilidade Técnica-Econômica. Pesquisa Agropecuária Brasileira, Dourados, v. 37 , p.1-9, 2016.

13. Hartman, G.L.; Sinclair, J.B.; Rupe, J.C. Compendium of soybean diseases. 4th ed. St Paul: APS Press, 1999. 100p.

14. Henning, A.A.; Almeida, A.M.R.; Godoy, C.V.; Seixas C.D.S.; Yorinori, J.T.; Costamilan, L.M.; Ferreira, L.P.; Meyer, M.C.; Soares R.M.; Dias W.P. Manual de identificação de doenças de soja. 5.ed. Londrina: Embrapa, 2014. 76p.

15. Holtz, V.; Couto, R.F.; Oliveira, D.G.; Reis, E.F. Deposição de calda de pulverização e produtividade da soja cultivada em diferentes arranjos espaciais. Ciência Rural, Santa Maria, v. 44, n.8, p.1371-1376, 2014.

16. Modolo, A.J.; Schidlowski, L.L.; Storck, L.; Benin, G.; Vargas, T.O.; Trogello, E. Rendimento de soja em função do arranjo de plantas. Revista de Agricultura, Piracicaba, v.91, n.3, p.216-229, 2016. Available at: $<$ http:// www.fealq.org.br/ojs/index.php/revistadeagricultura/article/view/143>. Accessed on: 20 set. 2017.

17. Petter, F.A.; Silva, J.A.; Zuffo, A.M; Andrade, F.R.; Pacheco, L.P.; Almeida, F.A. Elevada densidade de semeadura aumenta a produtividade da soja? Respostas da radiação fotossinteticamente ativa. Bragantia, Campinas v.75, n.2, p.173-183, 2016.

18. SAS Institute. SAS (Version 9.2) [Computer software] Cary, NC: SAS

19. Yorinori, J.T. Cancro da haste da soja: epidemiologia e controle. Londrina: Embrapa, 1996. 78p. 